\title{
Reducing Water Use during Cut-foliage Production
}

\author{
Robert H. Stamps \\ Central Florida Research and Education Center, University of Florida, Institute of Food and Agricultural \\ Sciences, 2807 Binion Road, Apopka, FL 32703
}

Florida's cut-foliage (CF) industry, which started in the 1890 s when the first sprays of plumosus fern [Asparagus setaceus (Kunth) Jessup] were shipped to florists (Manning, 1984), grew markedly beginning in the 1960 s due to the introduction of leatherleaf fern [Rumohra adiantiformis (Forst) Ching] and a new cold-protection technique. Growth of the CF industry, in combination with population increases in Florida's CF production areas, led to major conflicts in the 1980s over the use of water resources. These conflicts between horticultural and domestic water users have led to the formation of committees, establishment of several research studies, and enactment of water use regulations.

\section{Water for irrigation}

In 1956, 17 ha were used for leatherleaf fern production in Florida compared with 839 ha for plumosus fern (Chiang, 1958). By 1970, leatherleaf fern had displaced plumosus fern as Florida's predominant CF crop (Scarborough and Beshears, 1970), and, in 1987, there were $\approx 2000$ ha of leatherleaf fern (U.S. Dept. of Agriculture, 1987). Unlike plumosus fern production, for which permanent irrigation installations were impractical (Platt, 1952), irrigation was considered necessary for quality leatherleaf fern production (Conover and Loadholtz, 1970). The popularity of this durable CF crop and the subsequent increase in leatherleaf fern production area is primarily responsible for current problems regarding water use by Florida's CF industry.

Leatherleaf fern, a shallow-rooted perennial crop, is grown under natural or artificial shade on well-drained to excessively drained soils with limited water-holding capacity (Stamps and Conover, 1986). Although annual precipitation in Florida's CF production areas is $\approx 1250 \mathrm{~mm} \cdot$ year $^{-1}$, it occurs unevenly (Fig. 1; National Oceanic and Atmospheric Administration, 1989). Irrigation recommendations published in 1970 for commercial leatherleaf fern production called for $\approx 59 \mathrm{~mm}$ water/week during summer and $22 \mathrm{~mm} \cdot$ week $^{-1}$ during winter for a yearly total of $\approx 2480 \mathrm{~mm}$ (Conover and Loadholtz, 1970). These recommendations were designed to reduce water stress, which can markedly reduce plant growth. Two years later, the Florida Legislature passed Chapter 373 of the Florida Statutes, commonly referred to as the Florida Water Resources Act of 1972. This legislation created five regional water management agencies and charged those agencies, along with Florida's Dept. of Environmental Regulation (FDER), with managing water and related land resources and promoting conservation, development, and proper use of surface water and groundwater. Most leatherleaf fern production in Florida occurs in the St. Johns River Water Management District (SJRWMD).

In 1979, as a result of urging by the CF industry, the Univ. of Florida created a full-time faculty position for $\mathrm{CF}$ crop research. The $\mathrm{CF}$ specialist first determined the effects of reduced water application levels on yield and vase life of leatherleaf fem. This 3-year study showed that irrigating with $1500 \mathrm{~mm}$ water/year produced the same size and number of fronds as did irrigating with $3100 \mathrm{~mm}$ (Mathur et al., 1983). In addition, vase life of fronds receiving $1500 \mathrm{~mm}$ was increased $8 \%$ to $16 \%$ for three of seven harvests compared with fronds that received $3100 \mathrm{~mm}$.

Research regarding the use of tensiometers for scheduling irrigation of leatherleaf fern growing in Tavares-Millhopper fine sand was initiatedin 1985. Irrigation setpoints of $-5,-10,-15,-20$, and-25 $\mathrm{kPa}$ were used. Although frond sizes were similar for all irrigation treatments, frond yields from the -5 - and $-10-\mathrm{kPa}$ treatments were higher than those from the plots irrigated at more negative setpoints (Stamps, 1989a).

Water Conserv II, one of the largest U.S. projects using reclaimed water to irrigate horticultural crops, was established in Dec. 1986. This project provides secondarily treated and filtered sewage effluent from wastewater treatment facilities in Orlando and Orange County, Fla., free to growers who agree to take a set amount of water for 20 years (D'Angelo et al., 1985). This long-term water source, supplied at 276 $\mathrm{kPa}$ to the grower's property, ensures a dependable water source, reduces pumping costs, and supplies free nutrients. In 1987, the first $\mathrm{CF}$ operation was connected to this system, which can supply adequate water for both irrigation and cold protection.

\section{Water for cold protection}

Preventing cold damage of CF crops is especially important, because growers must provide $\mathrm{CF}$ throughout the year to satisfy their customers. Also, supplying CF crops for the major floral holidays (Valentine's through Mother's Day), when demand and prices are highest, is particularly important, because wholesale prices paid at other times during the year may be at or below production costs (Cunningham and Sheehan, 1989; Smith et al., 1988). Before the 1960 s heaters, rather than irrigation water, typically were used to protect plumosus fern from freezes, because growers found that irrigation systems in use at that time offered little cold protection (Platt, 1952). Leatherleaf fern can be damaged below -1C, so leatherleaf ferneries must also be heated during the winter in Florida (Henley et al., 1980).

Dean's $(1965,1966)$ research demonstrated that plumosus fern growing in a wood slat-roof fernery with solid wooden walls could be successfully cold-protected by irrigating at $\approx 10 \mathrm{~mm} \cdot \mathrm{h}^{-1}$ at minimum temperatures of $-4 \mathrm{C}$ under windy conditions and at $-7 \mathrm{C}$ under calm winds. Dean used rotary impact sprinklers with a 1-rpm average rotation rate. Since 1970 , the minimum water application rate recommended for cold protection of CF crops has been 8 to $9 \mathrm{~mm} \cdot \mathrm{h}^{-1}$ (Harrison and Conover, 1970). Using irrigation systems for cold protection of CF crops caught on rapidly, and today almost all CF crops are protected using overhead irrigation because using heaters is not economical (Castaldi, 1990).

In 1979, Univ. of Florida researchers requested funding from SJRWMD to study methods to reduce the amount of water necessary to protect leatherleaf fern from cold; however, SJRWMD did not respond. By 1979, leatherleaf fern accounted for $80 \%$ of Florida's CF production (Peacock and Scarborough, 1980). The following year, a SJRWMD study was published that reported 20-cm-diameter wells pumping 5678 liters water/min produced 3.5- to 5.7-m drawdowns of

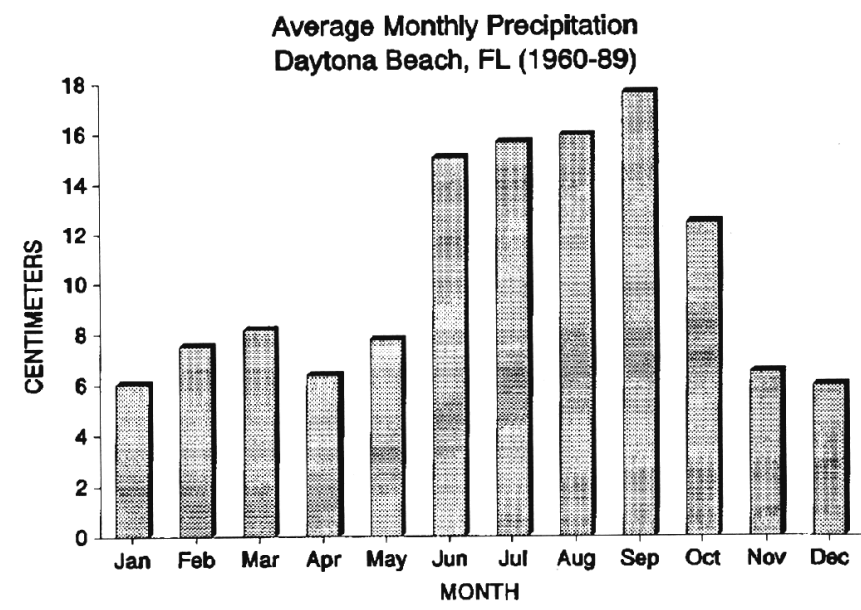

Fig. 1. Average monthly precipitation (in centimeters) at Daytona Beach, Fla., from 1960 through 1989. 
the Floridan aquifer after pumping $20 \mathrm{~h}$ for cold protection (Ross, 1980). The potentiometric surface recovered to near prefreeze condition in 1 day, and no significant changes in water quality were detected. Another SJRWMD study found that $60 \%$ of the groundwater used during 1980 for leatherleaf fern production at a l-ha fernery was for cold protection (Leary, 1982).

During Winter 1980-81, successful preliminary testing of frost protection sprinklers with $\approx 6$-rpm rotation rates that applied $5.2 \mathrm{~mm}$ water/hour (Stamps and Chase, 1981) suggested that it might be possible to reduce the amount of water recommended to protect leatherleaf fern growing in shadehouses. Dry-bulb temperatures recorded during these tests reached a $-12 \mathrm{C}$ low during the coldest radiation freeze. During the following winter, conventional impact sprinklers $(1.1 \mathrm{rpm})$ applying $8.6 \mathrm{~mm}$ water/hour were compared with frost protection impact sprinklers $(2.9 \mathrm{rpm})$ applying $4.6 \mathrm{~mm}$ water/ hour for leatherleaf fern cold protection. Similar results were documented for the two systems even though the frost protection sprinklers applied only slightly more than half as much water (Stamps and Mathur, 1982). These results agree with previous reports that suggest increased water application frequencies increased the effectiveness of sprinkling for frost protection (Wheaton and Kidder, 1965). However, neither application system provided adequate cold protection for leatherleaf fern when outside air temperatures dropped below $-4 \mathrm{C}$ and wind speeds were $>2.7 \mathrm{~m} \cdot \mathrm{s}^{-1}$.

Interest in the $\mathrm{CF}$ industry increased as Florida experienced the first "freeze of the century" during Dec. 1983 and the second freeze of the century in Jan. 1985. In Apr. 1985, SJRWMD approved "fern" criteria (Table 1) and defined critical areas to regulate cold protection water use by the CF industry. These criteria mandated water conservation methods such as dual irrigation systems (described below), tailwater recovery ponds, and reduced water application rates. The criteria applied to almost all CF growers, since it also applied to all consumptiveuse permit holders. The critical areas were those where $\mathrm{CF}$ production was concentrated and where the most complaints were received from homeowners whose shallow wells ran dry. SJRWMD asked the Univ. of Florida to submit a research proposal: "The purpose of the proposed research is to quantify and establish the parameters of irrigation water application rates and methods of application necessary to cold protect leatherleaf fern in production areas in order to present guidelines to the St. Johns River Water Management District for permitting water use for irrigation for cold protection." In June 1985, the SJRWMD Governing Board asked that a Fern Advisory Committee comprised of extension agents, Soil Conservation Service staff, and CF industry representatives work with the district to solve these problems.

Florida's CF industry was active in 1985. Growers lobbied for a well ordinance, which passed in Oct. 1985, that required at least $26 \mathrm{~m}$ of drop pipe on new wells constructed in northwestern Volusia County-the leading CF-producing county. This regulation would help ensure that new residential development in CF production areas would not lose their water supply during winter. In addition, a structured "Good Neighbor Policy" was implemented whereby complaints about domestic well problems were referred to designated $\mathrm{CF}$ growers. This policy was designed to help homeowners with shallow wells if their water supply was cut off. CF growers, along with a well specialist, would determine the cause of each well failure. They would fix the well if the water loss was due to groundwater drawdowns caused by a CF grower's pumping for cold protection. Growers voluntarily assessed their irrigated $\mathrm{CF}$ areas to provide funds for fixing the wells. The number of well complaints received by $\mathrm{CF}$ growers in Volusia County from 1985 to 1989 and the action taken are listed in Table 2. Volusia County growers spent $\$ 66,000$ to upgrade homeowner wells so that they would not run dry during a freeze (Krombach, 1990). Most of the upgrades involved increasing the amount of drop pipe in the wells.

In 1986, CF growers on the Soil Conservation District board in Putnam County, Florida's second largest CF producer, succeeded in securing funds for constructing cold protection research shadehouses at the Crescent City High School. Using these shadehouses during radiation freezes in Jan. 1987, researchers determined that using water to form ice to seal openings between shade fabric threads raised temperatures 1.0 to $3.6 \mathrm{C}$ in iced vs. noniced shadehouses (Stamps, 1989b). In addition, above-freezing temperatures were maintained in the iced shadehouse using $70 \%$ less water than in the noniced shadehouse. During the following year, a CF grower was granted U.S. patent no. 4,763,440 for this cold protection technique of using two irrigation systems-one above the crop and one above the shade fabric,

Field experiments testing spunbonded polypropylene covers for cold protection of CF crops were conducted during 1988 and 1989. In experiments using tree fern (Asparagus virgatus Bak.) growing in oak (Quercus spp.) hammocks, both $0.02-$ and $0.05-\mathrm{mg} \cdot \mathrm{mm}^{-2}$ covers prevented damage during radiation freezes (Stamps, 1990). Four spunbonded polyester and polypropylene crop covers were also evaluated with and without irrigation for cold protection of leatherleaf fern growing in shadehouses. Covers used alone during a radiation freeze decreased cold damage of immature fronds by $75 \%$ to $99 \%$ compared with no cover (Stamps, 1991). During an advective freeze, the cover/irrigation combination maintained temperatures at least $5 \mathrm{C}$ higher than irrigation alone. These results suggest that using crop covers could greatly reduce water use. However, given current materials and labor costs, it is unlikely that using crop covers would be economically feasible for relatively low-value crops such as leatherleaf fem. Fortunately, less expensive alternative cover materials may be forthcoming.

In Dec. 1989, Florida experienced its third freeze of the century, during which large amounts of water were withdrawn from the aquifer to cold-protect CF crops. As a consequence of withdrawing and applying large water quantities, a sinkhole formed in a road in Pierson, Fla. Temperature and irrigation data were collected at the Pierson research/teaching shadehouse facility during the freeze, and the dual irrigation system was tested again. During a radiation freeze on $4 \mathrm{Dec}$. with a minimum of $-5 \mathrm{C}$, temperatures at the top of the fern canopy were $\geq 1.7 \mathrm{C}$ in shadehouses where the irrigation rate was 5.3 or 7.1

Table 1. Fern criteria approved Apr. 1985 by the St. John's River Water Management District.

Renewals (regardless of location)

Goal: water conservation to minimize groundwater withdrawals

Require one of the following:

1) Install dual sprinkler system

2) Limit lower sprinkler output to $\approx 100 \mathrm{gal} / \mathrm{min} / \mathrm{acre}$

3) Construct Soil Conservation Service -approved tailwater/retention pond

4) District-approved alternative

All new systems (regardless of location)

Goal: water conservation to minimize groundwater withdrawals

Require one of the following:

1) Install dual sprinkler system

2) Limit lower sprinkler output to $\approx 100 \mathrm{gal} / \mathrm{min} /$ acre

3) Construct Soil Conservation Service -approved tailwater/retention pond

4) District-approved alternative

New systems (within critical area)

Goal: use alternate primary source for freeze protection (surface water)

Require tailwater/retention pond construction and one of the following:

1) Install dual sprinkler system

2) Limit lower sprinkler output to $\approx 100 \mathrm{gal} / \mathrm{min} /$ acre

3) District-approved alternative

Table 2. Numbers of complaints received about loss of water from domestic wells as part of Volusia County's Good Neighbor Policy Program from 1985 to 1989.

\begin{tabular}{lcccc}
\hline \hline Year & $\begin{array}{c}\text { Wells } \\
\text { fixed }^{\mathrm{z}}\end{array}$ & $\begin{array}{c}\text { Repair } \\
\text { delayed }^{\mathrm{y}}\end{array}$ & $\begin{array}{c}\text { Repair } \\
\text { disallowed }^{\mathrm{y}}\end{array}$ & $\begin{array}{c}\text { Total } \\
\text { complaints } \\
\text { by year }\end{array}$ \\
\hline 1985 & 1 & 0 & 0 & 1 \\
1986 & 26 & 0 & 11 & 37 \\
1987 & 13 & 5 & 1 & 19 \\
1988 & 7 & 0 & 2 & 9 \\
1989 & 56 & 12 & 9 & 77 \\
Total & 103 & 17 & 23 & 143 \\
\hline
\end{tabular}

${ }^{\mathrm{z}}$ Wells deepened, pumps and/or motors repaired or replaced.

${ }^{y}$ Households were slated to be hooked into a municipal water system.

xproblem not due to drawdown or cut foliage producer. 
$\mathrm{mm} \cdot \mathrm{h}^{-1}$, and $\geq 1.1 \mathrm{C}$ where the irrigation rate was $3.8 \mathrm{~mm} \cdot \mathrm{h}^{-1}$. However, frond temperatures during an advective freeze later that month, with ambient minima of $-7.8 \mathrm{C}$, were similar, regardless of rate, and maintained at $\approx 0 \mathrm{C}$. Damage to immature fronds ranged from $78 \%$ to $89 \%$ and was similar for all irrigation rates.

In early 1990, FDER received a special appropriation from the Florida Legislature to fund an on-farm survey of irrigation/chemigation systems and management practices used by CF growers. The SJRWMD, which eventually administered the FDER funds, also chartered the Citizens Advisory Committee (CAC) on Hydrologic Conditions in southern Putnam and northwestern Volusia counties. The CAC, composed of $\mathrm{CF}$ growers and homeowners, developed 37 watersaving recommendations and delivered them to SJRWMD's governing board in Oct. 1990. A dissenting subgroup of homeowners delivered a separate report to the board. The board took the reports under advisement (Krombach, 1990). At that time, Pierson's new municipal water system went on line, and Ormand Beach, Fla., located on Florida's east coast, attempted to establish amunicipal water well field near CF production areas. SJRWMD staff decided that municipalities with water well fields near CF production areas would have to construct water reservoirs, as CF growers were required to do (Table 1), so that the municipalities could switch from groundwater to surface water when cold protection of CF crops was necessary.

\section{Conclusion}

Obviously, water is a political issue in Florida's CF production areas. Politics can impede research on horticultural water use. The boards of many water management districts are appointed, and they fund what they consider to be major problems under their jurisdictions. However, these boards may, at times, be distracted from potentially important problems by current emotionally charged issues. In addition, board members generally have more experience with administration and regulation than with research, and they frequently want simple solutions to complex problems. The fact that it took 8 years and three severe freezes to convince the SJRWMD to fund needed cold protection research is evidence of the delays that can occur. After research is conducted, inappropriate or inaccurate interpretation and/or use of the results by regulatory agencies and special interest groups is a potential problem. Care must be taken that results are not applied out of context. This is an especially significant problem when there are few opportunities to collect data, as with cold protection research in Florida.

\section{Literature Cited}

Castaldi, M. 1990. Frost protection economics. Fruit Grower 110(1):6-7.

Chiang, T.I. 1958. Marketing Florida Asparagus plumosus ferns. PhD Diss., Univ. of Florida, Gainesville.

Conover, C.A. and L.L. Loadholtz. 1970. Leatherleaf fern production in Florida. Univ. of Florida, Inst. of Food and Agricultural Sciences, Florida Coop. Ext. Serv. Ornamental Hort. Rpt. 70-1.

Cunningham, J. and P. Sheehan. 1989. Marketing Florida ornamental crops, fresh flowers and ferns, summary 1987-88. Federal-State Market News Serv., Winter Park, Fla.

D’Angelo, S., K.L. Prime, Jr., and K.C. Rice. 1985. Water Conserv IIReclaimed water for citrus irrigation. Proc. Specialty Conf. Environ.
Engineering, EE Div., Amer. Soc. Civil Eng., Boston, 1-5 July 1985.

Dean, R.H. 1965. Preliminary report on use of water sprinklers for protection of fern against freeze damage. Univ. of Florida, Inst. of Food and Agricultural Sciences, Florida Agr. Ext. Serv. Florida Foliage Grower 2(6):1-4.

Dean, R.H. 1966. Use of water sprinklers to protect fern against freeze damage. Proc. Fla. State Hort. Soc. 79:420-424.

Harrison, D.S. and C.A. Conover. 1970. Irrigation of leatherleaf and plumosus ferns. Univ. of Florida, Inst. of Food and Agricultural Sciences, Agricultural Engineering Dept. Mimeo Rpt. 70-7.

Henley, R.W., B. Tjia, and L.L. Loadholtz. 1980. Commercial leatherleaf fern production in Florida. Univ. of Florida, Inst. of Food and Agricultural Sciences, Florida Coop. Ext. Serv. Bul. 191.

Krombach, A. 1990. Drought, freeze plague growers. Fern, October supplement to the Courier-Journal, Crescent City, Fla.

Leary, P.L. 1982. Investigation of fern water use in southeast Putnam County. St. Johns River Water Management District, Palatka, Fla., Tech. Publ. SJ 82-3.

Manning, R.D. 1984. From orange to green "gold": The roots of the asparagus fern industry in Florida. Fla. Historical Quart. 62(4):464-484.

Mathur, D.D.; R.H. Stamps, and C.A. Conover. 1983. Response of Rumohra adiantiformis to water application level and nitrogen form. HortScience $18: 759-760$

National Oceanic and Atmospheric Administration. 1989. Local climatological data, Daytona Beach, Fla. Natl. Oceanic and Atmospheric Admin., Natl. Climatic Data Cntr., Asheville, N.C.

Peacock, S. and E.F. Scarborough. 1980. Marketing Florida ornamental crops, fresh flowers and ferns, summary 1979-80 season. Fed.-State Market News Serv., Winter Park, Fla.

Platt, W.J., Jr. 1952. Asparagus fern culture. Florida Agr. Ext. Serv. Bul. 153.

Ross, F.W. 1980. Effects on the Floridan aquifer of ground water withdrawals for fernery freeze protection, southeast Putnam County, Florida. St. Johns River Water Management District, Palatka, Fla., Tech. Publ. SJ 80-8.

Scarborough, E.F. and F.H. Beshears. 1970. Marketing Florida ornamental crops, flowers and ferns, summary 1971 season. Fed.-State Market News Serv., Orlando, Fla.

Smith, S.A., T.G. Taylor, and L.L. Loadholtz. 1988. Cost of production for leatherleaf ferns in Florida. Univ. of Florida, Inst. of Food and Agricultural Sciences, Food and Research Economics Dept. Staff Paper 342.

Stamps, R.H. 1989a. Effects of irrigation scheduling using tensiometers on leatherleaf fem. HortScience 24:100. (Abstr.)

Stamps, R.H. 1989b. Icing of shade fabric enhances cold protection of shadehouses during radiation freezes. HortScience 24:517.

Stamps, R.H. 1990. Spunbonded polypropylene covers aid cold protection of Asparagus virgatus during radiation freezes. Proc. Fla. State Hort. Soc. 103:158-159.

Stamps, R.H. 1991. Cold protection of leatherleaf fern using crop covers and overhead irrigation in shadehouses. HortScience 26:862-865.

Stamps, R.H. and A.R. Chase. 1981. Protecting leatherleaf fern from cold damage-Winter 1980-81. Univ. of Florida, Inst. of Food and Agricultural Sciences, Agr. Res. Cntr.-Apopka Res. Rpt. RH-81-10.

Stamps, R.H. and C.A. Conover. 1986. Cut foliage production in Florida. Ho\&Science 21:178, 343.

Stamps, R.H. and D.D. Mathur. 1982. Reduced water application rates and cold protection of leatherleaf fem. Proc. Fla. State Hort. Soc. 95:153-155.

U.S. Dept. of Agriculture. 1987. Floriculture crops, 1987 summary. U.S. Dept. of Agriculture, Natl. Agricultural Statistics Serv., Agricultural Statistics Board, Washington, D.C.

Wheaton, R.Z. and E.P. Kidder. 1965. The effect of frequency of application on frost protection by sprinkling. Quart. J. Mich. State Univ., Agr. Expt. Sta. $47: 439-445$. 